\title{
Pemberian Ekstrak Daun Cincau (Mesona palustris BL) Meningkatkan Kadar Superoksida Dismutase (SOD) Tikus Wistar (Rattus norvegicus) Jantan yang Diinduksi Latihan Fisik Berlebih
}

\author{
${ }^{1}$ Karnia Tarnajaya, ${ }^{2}$ Alex Pangkahila, ${ }^{2}$ Wimpie Pangkahila, ${ }^{3}$ Ferbian M. Siswanto \\ ${ }^{1}$ Program Pascasarjana Anti-Aging Medicine Universitas Udayana Denpasar \\ ${ }^{2}$ Departemen Andrologi dan Seksologi Fakultas Kedokteran Universitas Udayana Denpasar \\ ${ }^{3}$ Departement of Biomedical Chemistry, Kwansei Gakuin University, Sanda, Hyogo, Japan \\ E-mail: ferbianms@kwansei.ac.jp
}

\begin{abstract}
This study was aimed to prove that administration of black cincau (Mesona palustris BL) leaf extract increased superoxide dismutase (SOD) levels of overtraininginduced male Wistar rats (Rattus norvegicus). This was a true experimental study using the randomized pretest-posttest control group design. Subjects were 16 male rats (Rattus norvegicus), 6-month old, Wistar strain, weighing 180-200 g, SOD level $<39.3 \mathrm{U} / \mathrm{mL}$ (normal SOD level), divided into two groups: the control group (P0) and the treatment group (P1). The P0 group was given excessive physical training and aquadest for 14 days, while the P1 group was given excessive physical training and black cincau leaf extract of $54 \mathrm{mg} / 200 \mathrm{~g} \mathrm{BW}$ daily for 14 days. The results showed that the mean SOD level before treatment (pretest) in the P0 group was $30.63 \pm 2.26 \mathrm{U} / \mathrm{mL}$ while in the $\mathrm{P} 1$ group was $31.31 \pm 2.52 \mathrm{U} / \mathrm{mL}(P>0.05)$. After 14day treatment (posttest), the mean SOD level in the P0 group was $29.36 \pm 2.83 \mathrm{U} / \mathrm{mL}$ while in the $\mathrm{P} 1$ group was $41.31 \pm 2.35 \mathrm{U} / \mathrm{mL}(P<0.01)$. Further analysis showed that there was no change of SOD levels in the $\mathrm{P} 0$ group $(P>0.05)$, but in the $\mathrm{P} 1$ group there was a significant increase of SOD levels from $31.31 \pm 2.52 \mathrm{U} / \mathrm{mL}$ to $41.31 \pm 2.35 \mathrm{U} / \mathrm{mL}(P<0.01)$. Conclusion: Administration of black cincau leaf extract of $54 \mathrm{mg}$ per $200 \mathrm{~g}$ of body weight increased SOD level of overtraining-induced male Wistar rats (Rattus norvegicus).
\end{abstract}

Keywords: black cincau leaves, SOD, excessive physical activity

\begin{abstract}
Abstrak: Penelitian ini bertujuan untuk membuktikan bahwa pemberian ekstrak daun cincau (Mesona palustris BL) dapat meningkatkan kadar superoksida dismutase (SOD) tikus Wistar (Rattus norvegicus) jantan yang diinduksi pelatihan fisik berlebih. Jenis penelitian ialah eksperimental murni menggunakan randomized pretest-posttest control group design. Subjek penelitian ialah 16 ekor tikus putih jantan (Rattus norvegicus) galur Wistar berumur 6 bulan, sehat, berat badan 180-200 gr, dan kadar SOD $<39,3$ U/mL (kadar SOD normal), yang dibagi menjadi dua kelompok, yaitu kelompok kontrol (P0) dan kelompok perlakuan (P1), masingmasing berjumlah 8 ekor tikus. Kelompok P0 diberikan pelatihan fisik berlebih dan akuades secara sonde selama 14 hari, dan kelompok P1 diberikan pelatihan fisik berlebih dan ekstrak daun cincau dosis $54 \mathrm{mg} / 200$ gr BB tikus selama 14 hari. Hasil penelitian menunjukkan bahwa rerata kadar SOD sebelum perlakuan (pretest) pada kelompok P0 ialah 30,63 $\pm 2,26 \mathrm{U} / \mathrm{mL}$, sedangkan pada kelompok P1 ialah 31,31 $\pm 2,52 \mathrm{U} / \mathrm{mL}(P>0,05)$. Setelah perlakuan selama 14 hari (posttest), rerata kadar SOD pada kelompok P0 ialah 29,36 $\pm 2,83 \mathrm{U} / \mathrm{mL}$, dan pada kelompok P1 ialah 41,31 $\pm 2,35 \mathrm{U} / \mathrm{mL}(P<0,01)$. Hasil analisis efek perlakuan menunjukkan bahwa pada kelompok P0 tidak terjadi perubahan kadar SOD $(P>0,05)$, namun pada kelompok P1 terjadi peningkatan bermakna kadar SOD dari 31,31 $\pm 2,52 \mathrm{U} / \mathrm{mL}$ menjadi $41,31 \pm 2,35 \mathrm{U} / \mathrm{mL}(P<0,01)$. Simpulan: Ekstrak daun cincau dosis $54 \mathrm{mg} / 200$ gr BB tikus dapat meningkatkan kadar SOD tikus Wistar (Rattus norvegicus) jantan yang diinduksi pelatihan fisik berlebih.
\end{abstract}

Kata kunci: daun cincau, SOD, aktivitas fisik berlebih 
Setiap makhluk hidup memiliki siklus kehidupan yang berjalan seiring dengan waktu. Faktor-faktor yang dapat menyebabkan penuaan secara garis besar dibagi menjadi faktor eksternal dan faktor internal. ${ }^{1}$ Salah satu faktor yang paling banyak dipelajari ialah akumulasi kerusakan oksidatif yang disebabkan oleh tingginya radikal bebas dalam tubuh. ${ }^{2}$

Radikal bebas adalah molekul atau atom yang mengandung satu atau lebih elektron yang tidak berpasangan pada orbit luarnya sehingga cenderung memperoleh elektron dari molekul lain yang menjadikan radikal bebas bersifat sangat reaktif. ${ }^{2}$ Radikal bebas dapat berasal dari dalam tubuh maupun luar tubuh. Radikal bebas yang berasal dari dalam tubuh dapat terjadi akibat proses enzimatik (oleh mitokondria, membran plasma, lisosom, retikulum endoplasma, dan inti sel) maupun akibat proses non-enzimatik (pada reaksi inflamasi dan iskemia). Radikal bebas yang berasal dari luar tubuh diakibatkan oleh adanya polutan seperti asap rokok, asap kendaraan bermotor, radiasi sinar ultraviolet (UV), sinar X, sinar gamma, konsumsi makanan tinggi lemak, kafein, alkohol, pestisida, atau zat beracun lainnya. Selain itu terbentuknya radikal bebas juga dapat dipicu oleh adanya stres atau pelatihan fisik berlebih. ${ }^{3}$

Pelatihan fisik berlebih dan pengaruh lingkungan secara tidak langsung dapat menyebabkan terbentuknya radikal bebas. Pelatihan fisik berlebih meningkatkan reactive oxygen species (ROS) dalam jaringan, dan 2-5\% oksigen yang dipakai dalam metabolisme tereduksi menjadi ion superoksid yang bersifat radikal bebas. Pelepasan radikal bebas akan terlibat dalam proses oksidasi lemak membran sel otot, yang disebut peroksidasi lipid dan menyebabkan sel menjadi lebih mudah mengalami proses penuaan atau kerusakan lain. ${ }^{4}$

Tingginya kadar radikal bebas mengakibatkan menurunnya aktivitas antioksidan enzim yaitu superoksida dismutase (SOD), katalase, glutation dan glutation peroksidase karena antioksidan enzimatik tersebut secara langsung menetralisasi radikal bebas dan dimetabolisme menjadi senyawa lain di dalam tubuh. ${ }^{5}$ Ketidakseimbangan antara pembentukan radikal bebas dan sistem scavenging menghasilkan suatu keadaan yang disebut stres oksidatif dan dapat menyebabkan kerusakan sel. ${ }^{6}$

Pelatihan fisik berlebih akan menyebabkan peningkatan produksi radikal bebas yang berlanjut dengan stres oksidatif. ${ }^{7}$ Terjadinya stres oksidatif mengakibatkan peroksidasi komponen lipid dari asam lemak tak jenuh yang terjadi pada membran sel. ${ }^{8}$

Daun cincau (Mesona palustris BL) merupakan bahan pangan tradisional yang mengandung antioksidan cukup tinggi dan secara empiris daun cincau diyakini berkhasiat untuk mencegah stres oksidatif. ${ }^{9}$ Senyawa fenolik atau total fenol merupakan komponen bioaktif daun yang mempunyai sifat antioksidan yang digolongkan sebagai antioksidan eksogen. Senyawasenyawa tersebut dicirikan memiliki satu atau lebih gugus hidroksil pada cincin aromatis. Turunan senyawa fenol banyak terjadi secara alami sebagai flavonoid, alkaloid, tannin, dan senyawa fenolat lain. ${ }^{10}$ Senyawa flavonoid merupakan kelompok fenol terbesar di alam. Flavonoid bersifat antioksidan dan telah digunakan sebagai salah satu komponen bahan baku obatobatan. ${ }^{11}$

Hasil analisis fitokimia yang dilakukan di Laboratorium Teknologi Pertanian, Universitas Udayana menunjukkan bahwa ekstrak daun cincau mengandung flavonoid, fenol, tannin, dengan kapasitas antioksidan sebesar 1054,7600 mg/L dan Inhibition Concentration 50 (IC50) sebesar $4,3670 \mathrm{mg} / \mathrm{ml}$ yang tergolong sebagai antioksidan yang sangat kuat. ${ }^{12}$

Daun cincau mudah ditemukan di Indonesia. Pada penelitian ini daun tersebut didapatkan dari tanaman lahan terbuka di Pagar Alam, Sumatera Selatan. Proses ekstraksi dilakukan dengan cara maserasi menggunakan pelarut etanol 96\%. ${ }^{13}$ Meskipun penelitian sebelumnya melaporkan bahwa daun cincau merupakan salah satu sumber antioksidan yang baik, namun belum ada penelitian yang melaporkan ekstrak daun cincau dapat meningkatkan kadar antioksidan endogen seperti (SOD) 
pada tikus yang mengalami stres oksidatif dengan pelatihan fisik berlebih.

\section{METODE PENELITIAN}

Untuk membuktikan bahwa pemberian ekstrak daun cincau (Mesona palustris BL) dapat meningkatkan kadar SOD tikus Wistar (Rattus norvegicus) jantan yang diinduksi pelatihan fisik berlebih, maka dilakukan penelitian eksperimental menggunakan randomized pretest-posttest control group design. Pada penelitian ini digunakan 16 ekor tikus (Rattus norvegicus), galur Wistar, jenis kelamin jantan, sehat, berumur 6 bulan (setara 18 tahun umur manusia) dengan berat badan sekitar 180-200 gr, yang dibagi menjadi 2 (dua) kelompok masing-masing berjumlah 8 ekor tikus. Kelompok pertama (P0) ialah kelompok kontrol yang diberikan pelatihan fisik berlebih dan plasebo berupa akuades $3 \mathrm{ml}$, dan kelompok kedua (P1) ialah kelompok perlakuan yang diberikan pelatihan fisik berlebih dan ekstrak daun cincau (Mesona palustris $\mathrm{BL}$ ) dosis $54 \mathrm{mg} / 200$ gr BB tikus melalui sonde.

Sebelum diberikan perlakuan, seluruh kelompok tikus diinduksi pelatihan fisik berlebih selama 7 hari dan dilakukan pemeriksaan kadar SOD pretest. Setelah itu dilakukan perlakuan berdasarkan kelompok selama 14 hari kemudian dilakukan pemeriksaan kadar SOD posttest. Pemeriksaan kadar SOD dilakukan dengan menggunakan SOD Assay Kit dari perusahaan Biovision dengan merk Biovision.

\section{HASIL PENELITIAN}

Hasil penelitian menunjukkan bahwa rerata kadar SOD pada kelompok kontrol (P0) sebelum diberikan perlakuan (pretest) ialah $30,63 \pm 2,26 \mathrm{U} / \mathrm{mL}$, sedangkan pada kelompok perlakuan (P1) sebelum diberikan perlakuan (pretest) ialah 31,31 $\pm 2,52$ $\mathrm{U} / \mathrm{mL}$. Analisis kemaknaan menggunakan Independent Sample T-Test menunjukkan bahwa nilai $t=-0,564$ dan nilai $P=0,582$, yang menunjukkan bahwa kadar SOD pada kedua kelompok sebelum diberikan perlakuan tidak berbeda bermakna $(P>0,05)$.

Hasil penelitian menunjukkan bahwa rerata kadar SOD pada kelompok P0 sesudah diberikan pelatihan fisik berlebih dan akuades 3ml selama 14 hari (posttest) ialah 29,36 $\pm 2,83 \mathrm{U} / \mathrm{mL}$, sedangkan pada kelompok P1 diberikan pelatihan fisik berlebih dan ekstrak daun cincau (Mesona palustris BL) dosis $54 \mathrm{mg} / 200 \mathrm{gr}$ BB tikus secara sonde selama 14 hari (posttest) ialah 41,31 $\pm 2,35 \mathrm{U} / \mathrm{mL}$. Analisis kemaknaan dengan Independent Sample T-Test menunjukkan nilai $t=-9,191$ dan nilai $P=0,000$, yang berarti bahwa kadar SOD pada kelompok P1 secara statistik lebih tinggi bermakna dibandingkan kelompok P0 ( $P$ $<0,01$ ) (Tabel 1).

Hasil analisis efek perlakuan menunjukkan bahwa pada kelompok P0 tidak terjadi perubahan kadar SOD setelah 14 hari diberikan pelatihan fisik berlebih dan akuades 3ml $(P>0,05)$. Namun sebaliknya, pada kelompok P1 terjadi peningkatan kadar SOD yang bermakna dari 31,31 $\pm 2,52$ $\mathrm{U} / \mathrm{mL}$ menjadi 41,31 $\pm 2,35$ setelah 14 hari diberikan pelatihan fisik berlebih dan ekstrak daun cincau (Mesona palustris BL) dosis $54 \mathrm{mg} / 200$ gr BB tikus secara sonde $(P<0,01)$ (Tabel 2).

Tabel 1. Analisis komparabilitas data

\begin{tabular}{lcccccc}
\hline \multirow{2}{*}{ Pemeriksaan } & Kelompok & n & $\begin{array}{c}\text { Rerata kadar } \\
\text { SOD (U/mL) }\end{array}$ & SB & t & \multirow{2}{*}{} \\
\hline \multirow{2}{*}{ Pretest } & Kelompok P0 & 8 & $30,63 \pm 2,26$ & 2,08 & \multirow{2}{*}{0,564} & \multirow{2}{*}{0,582} \\
\multirow{2}{*}{ Posttest } & Kelompok P1 & 8 & $31,31 \pm 2,52$ & 3,41 & & \\
& Kelompok P0 & 8 & $29,36 \pm 2,83$ & 0,55 & $-9,191$ & 0,000 \\
\hline
\end{tabular}

$\mathrm{n}=$ jumlah sampel; $\mathrm{SB}=$ Simpangan Baku; $t=$ distribusi t hitung; $P=$ signifikansi 
12 Jurnal Biomedik (JBM), Volume 10, Nomor 1, Maret 2018, hlm. 9-15

Tabel 2. Analisis efek perlakuan

\begin{tabular}{lcccc}
\hline \multicolumn{1}{c}{ Kelompok } & Rerata Pretest & Rerata Posttest & $\boldsymbol{t}$ & $\boldsymbol{P}$ \\
\hline Kontrol (P0) & $30,63 \pm 2,26$ & $29,36 \pm 2,83$ & 1,119 & 0,300 \\
Perlakuan (P1) & $31,31 \pm 2,52$ & $41,31 \pm 2,35$ & $-9,060$ & 0,000 \\
\hline
\end{tabular}

\section{BAHASAN}

Ketika melakukan pelatihan fisik yang cukup berat, terjadi peristiwa iskemiareperfusi yang dapat meningkatkan produksi radikal bebas, dimana peningkatan pasokan oksigen (oxygen supply) sering kali tidak mampu memenuhi kebutuhan oksigen (oxygen demand); fenomena ini disebut sebagai fase iskemia. Sementara itu peningkatan pasokan oksigen yang tinggi justru akan meningkatan pembentukan radikal bebas oksigen bahkan bisa mencapai $10 \mathrm{x}$ lipat; fenomena ini disebut fase reperfusi. Beberapa penelitian telah membuktikan bahwa pelatihan fisik berlebih dapat menyebabkan stres oksidatif dimana produksi radikal bebas oksigen meningkat secara bermakna. ${ }^{4,14}$

Pada penelitian ini, subjek penelitian tikus Wistar jantan diinduksi pelatihan fisik berlebih yaitu perenangan hingga menyebabkan kondisi overtraining yang ditandai dengan kondisi kelelahan berupa tikus hampir tenggelam oleh karena menurunnya kekuatan otot, waktu reaksi, frekuensi gerakan, dan refleks. Pelatihan fisik berlebih (overtraining) diberikan dalam jangka waktu 7 hari sebelum penelitian dimulai untuk menginduksi penurunan SOD. ${ }^{15,16}$ Pengambilan waktu 7 hari didasarkan atas hasil penelitian sebelumnya yang melaporkan kemampuan waktu renang maksimal tikus wistar hingga hampir tenggelam berkisar 60 menit. $^{15,16}$ Selain itu hasil penelitian ini juga menunjukkan pada pemeriksaan pretest kadar SOD lebih rendah dibandingkan kadar SOD normal dalam penelitian Sulaiman. ${ }^{17}$

Jumlah radikal bebas dan mekanisme adaptasi pada tikus meningkat secara bermakna, berkaitan dengan jumlah konsumsi oksigen. Radikal oksigen terbentuk oleh adanya reduksi oksigen yang tidak sempurna. Latihan fisik yang mendadak menyebabkan peningkatan konsumsi oksigen, yang berlanjut dengan peningkatan pembentukan radikal bebas. Peningkatan molekul radikal juga terjadi dalam perpanjangan latihan dan latihan dengan intensitas tinggi, namun pelatihan fisik seimbang mampu mengadaptasi mencegah efek berbahaya dari radikal oksigen bebas. ${ }^{18}$ Pelatihan fisik berlebih meningkatkan ROS dalam jaringan, dan sekitar 2-5\% oksigen yang dipakai dalam metabolisme tereduksi menjadi ion superoksid yg bersifat radikal bebas. Kondisi ini akan menyebabkan stres oksidatif. ${ }^{4,7}$ Hasil penelitian menyebutkan bahwa pelatihan fisik berlebih dapat menginduksi stres oksidatif, serta menurunkan aktivitas dan kadar SOD, glutation (GSH), dan katalase pada eritrosit. ${ }^{19}$ Hal ini disebabkan karena SOD merupakan salah satu antioksidan endogen yang berfungsi mengatalisis reaksi dismutasi radikal bebas anion superoksida $\left(\mathrm{O}_{2}{ }^{-}\right)$menjadi hidrogen peroksida dan molekul oksigen. ${ }^{5}$ Superoksida dismutase berperan untuk mengikat radikal bebas dan mengubahnya menjadi bentuk yang tidak berbahaya. ${ }^{20}$

Hasil penelitian ini menunjukkan bahwa pemberian ekstrak daun cincau dapat meningkatkan kadar SOD yang menurun akibat pelatihan fisik berlebih. Perlakuan selama 7 hari awal dapat menurunkan kadar SOD yang didukung oleh penelitian Sulaiman ${ }^{17}$ dan juga oleh teori yang menjelaskan stres oksidatif dapat menurunkan kadar SOD. ${ }^{20}$ Setelah diinduksi lebih lanjut selama 14 hari kemudian (total perlakuan menjadi 21 hari) kemungkinan tikus pada kelompok kontrol telah beradaptasi dan dapat mencegah penurunan kadar SOD lebih lanjut. Teori ini dikenal dengan istilah stress hormesis. Pemberian pelatihan fisik berlebih dapat meningkatkan ROS dan menurunkan kadar SOD. Namun dengan pemberian pelatihan fisik berlebih 
yang kronis dalam jangka waktu panjang, maka kadar SOD dapat kembali ke nilai normal tanpa diberikan intervensi apapun. Ketika rangsangan stres oksidatif pertama kali diberikan (bersifat akut) maka akan menginduksi penurunan kadar SOD karena steady state level SOD berada pada ambang normal, namun semakin sering frekuensi stres yang diberikan akan meningkatkan steady state level SOD sehingga stres oksidatif yang diberikan pada saat ini cenderung tidak menurunkan kadar SOD dibandingkan nilai normal karena steady state level yang telah meningkat.

Berdasarkan hasil penelitian ini dapat disimpulkan bahwa pelatihan fisik berlebih selama 7 hari dapat menurunkan kadar SOD secara bermakna, namun jika diberikan lebih lanjut hingga 21 hari (14 hari tambahan dari 7 hari) tubuh telah berhasil mengembangkan mekanisme adaptasi sehingga kadar SOD tidak menurun karena steady state levels yang telah meningkat. ${ }^{21,22}$

Namun dilain pihak, pada kelompok perlakuan yang diberikan ekstrak daun cincau terjadi peningkatan kadar SOD yang bermakna. Hal ini dapat terjadi karena induksi stress hormesis ataupun karena pemberian ekstrak daun cincau. Pelatihan fisik berlebih kronis yang diberikan selama 21 hari dapat meningkatkan steady state level dari SOD, ${ }^{21,22}$ dan juga didukung oleh aktivitas antioksidan dari ekstrak daun cincau. Hasil penelitian ini secara garis besar serupa dengan hasil penelitian terdahulu yang juga telah banyak membuktikan efek antioksidan yang cukup potensial pada ekstrak daun cincau. Penelitian menunjukkan bahwa pemberian ekstrak cincau hitam dosis $1,890 \mathrm{mg} / \mathrm{kg}$ BB dapat menurunkan kadar malondialdehida (MDA) yang merupakan biomarker stres oksidatif hingga $68,77 \% .^{23}$ Penelitian lainnya juga membuktikan bahwa ekstrak cincau hitam dosis $135 \mathrm{mg} / \mathrm{kg}$ BB per hari dapat mencegah kerusakan hati yang diinduksi etanol dosis toksik yang ditunjukkan dengan menurunnya kadar SGPT dan SGOT; serta mencegah oksidatif stres yang ditandai dengan menurunnya kadar MDA dan meningkatnya kadar SOD. ${ }^{24}$ Hasil penelitian ini dan penelitian terdahulu terkait dengan kandungan senyawa bioaktif di dalam ekstrak daun cincau (Mesona palustris $\mathrm{BL}$ ).

Hasil analisis fitokimia yang dilakukan di Laboratorium Teknologi Pertanian, Universitas Udayana menunjukkan bahwa ekstrak daun cincau mengandung flavonoid sebesar 432,879 mg/100gQE, total fenol sebesar 653,555 mg/100gQE, tannin sebesar 213,2500 mg/100gQE, dengan kapasitas antioksidan sebesar 1054,7600 $\mathrm{mg} / \mathrm{L}$ dan Inhibition Concentration 50 (IC50) sebesar $4,3670 \mathrm{mg} / \mathrm{ml}$. IC50 dapat didefinisikan sebagai konsentrasi larutan sampel yang akan menyebabkan reduksi terhadap aktivitas DPPH sebesar 50\%. Semakin kecil nilai IC50 menunjukkan aktivitas antioksidan semakin tinggi. Suatu senyawa dikatakan sebagai antioksidan yang sangat kuat bila nilai IC50 $<50$ $\mathrm{mg} / \mathrm{ml}$; kuat bila nilai IC50 50-100 mg/ml; sedang bila nilai IC50 100-150 mg/ml; dan lemah bila nilai IC50 150-200 mg/ml. ${ }^{12}$ Dengan demikian ekstrak daun cincau dalam penelitian ini dengan IC50 sebesar $4,3670 \mathrm{mg} / \mathrm{ml}$ tergolong antioksidan yang sangat kuat.

Penelitian menemukan bahwa flavonoid dapat meningkatkan aktivitas SOD dan katalase yang bertanggung jawab atas penurunan tingkat produk peroksidasi lipid seperti MAD, hidroperoksida, dan diena terkonjugasi. $^{25,26}$ Kandungan flavonoid dapat meredam efek buruk radikal bebas, dengan menghambat peroksidasi lipid melalui aktivasi peroksidase terhadap hemoglobin, yang merupakan antioksidan endogen (enzimatiK) seperti SOD dan katalase. ${ }^{27}$ Peroksidase bermanfaat untuk mencegah penimbunan $\mathrm{H}_{2} \mathrm{O}_{2}$, yang keberadaannya menjadi berbahaya jika bersama-sama $\mathrm{O}_{2} \bullet$ karena dapat membentuk radikal $\bullet \mathrm{OH}$ yang merupakan radikal bebas paling reaktif dan paling berbahaya, yang dapat merusak membran sel dengan menyebabkan terputusnya asam lemak tidak jenuh. ${ }^{28}$ Selain itu kandungan flavonoid diketahui merupakan antioksidan pemutus rantai (chain breaking antioxidants) yang larut dalam lemak dan bekerja pada membran sel yang dapat 
memutus rantai peroksidasi lipid. ${ }^{6}$

Efek flavonoid terhadap ROS terjadi melalui dua mekanisme yaitu dengan menangkap radikal bebas/menetralisasi dan meningkatkan antioksidan endogen seperti SOD. Peningkatan antioksidan endogen oleh flavonoid telah terbukti dalam penelitian in vitro melalui peningkatan faktor transkripsi Nrf2 yang meningkatkan ekspresi protein HO1 dan SOD. ${ }^{29}$ Flavonoid dapat mengaktifkan ERK, JNK, dan p38 yang merupakan kinase berperan dalam fosforilasi Nrf2 dan meningkatkan kadar Nrf2 dalam sitoplasma, selanjutnya Nrf2 yang terakumulasi pada sitoplasma dapat bertranslokasi kedalam nukleus dan berikatan dengan antioxidant responsive element (ARE) sehingga mengaktifkan transkripsi gen antioksidan endogen seperti SOD, HO-1, dan NQO1. ${ }^{30}$

Limitasi penelitian ini ialah bahwa penelitian ini bersifat in vivo sehingga tidak dapat mempelajari mekanisme kerja ekstrak daun cincau secara langsung pada tingkat sel dan molekul. Perlakuan yang digunakan ialah pemberian ekstrak daun cincau yang mengandung banyak senyawa bioaktif sehingga tidak diketahui senyawa bioaktif mana yang paling berperan dalam meningkatkan kadar SOD. Oleh karena itu perlu dilakukan penelitian lebih lanjut untuk mengetahui mekanisme kerja molekuler ekstrak daun cincau (Mesona palustris BL) dalam meningkatkan kadar SOD tikus Wistar yang diinduksi latihan fisik berlebih, apakah secara langsung atau tidak langsung melalui interaksi dengan komponen sel lainnya.

\section{SIMPULAN}

Berdasarkan hasil penelitian ini, dapat disimpulkan bahwa pemberian ekstrak daun cincau (Mesona palustris BL) dosis $54 \mathrm{mg} / 200$ gr BB tikus dapat meningkatkan kadar superoksida dismutase (SOD) tikus Wistar (Rattus norvegicus) jantan yang diinduksi pelatihan fisik berlebih.

\section{DAFTAR PUSTAKA}

1. Pangkahila W. Anti Aging Medicine: Memperlambat Penuaan, Meningkat- kan Kualitas Hidup (2nd ed). Jakarta:

Penerbit Buku Kompas, 2011.

2. Ahmed MF, Rao AS, Ahemad SR, Ibrahim

M. Phytochemical studies and antioxidant activity of Brassica oleracea L.var. capitata. Int J Pharm Pharm Sci. 2012;4(3):374-8.

3. Pham-Huy LAP, He H, Pham-Huy C. Free radicals, antioxidants in disease and health. Int J Biomed Sci. 2008;4:89-96.

4. Tanskanen M, Atalay M, Uusitalo A. Altered oxidative stress in overtrained athletes. J Sports Sci. 2010;28(3):309-17.

5. Birben E., Sahiner UM, Sackesen C, Erzurum S, Kalayci O. Oxidative stress and antioxidant defense. World Allergy Organ J. 2012;5(1):9-19.

6. Murray RK. Harper's Illustrated Biochemistry. USA: McGraw-Hill, 2009; p. 101.

7. Yavari A, Javadi M, Mirmiran P, Bahadoran Z. Exercise-induced oxidative stress and dietary antioxidants. Asian J Sports Med. 2015;6(1):e24898.

8. Barrera G. Oxidative stress and lipid peroxidation products in cancer progression and therapy. ISRN Oncol. 2012;2012:137289.

9. Widyaningsih TD. Potensi cincau hitam (Mesona palustris BL) sebagai bahan pangan fungsional yang bersifat imunomodulator. Prosiding Seminar Pengembangan Teknologi Berbasis Bahan Baku Lokal. Yogyakarta: LIPI, 2009; p. 214- 218.

10. Saboonchian F, Jamei R, Hosseini Sarghein S. Phenolic and flavonoid content of Elaeagnus angustifolia L. (leaf and flower). Avicenna J Phytomed. 2014;4(4):231-8.

11. Grafianita. Kadar kurkuminoid, total fenol dan aktivitas antioksidan Simplisia Temulawak (Curcuma xanthorrhiza Roxb) pada berbagai teknik pengeringan [Skripsi]. Surakarta: Universitas Sebelas Maret; 2011.

12. Sebaugh JL. Guidelines for accurate EC50/IC50 estimation. Pharm Stat. 2011;10(2):128-34.

13. Maslukhah Y, Widyaningsih TD, Waziiroh, E, Wijayanti N. Faktor pengaruh ekstraksi cincau hitam (Mesona palustris BL) skala pilot plant: Kajian Pustaka. Jurnal Pangan dan Agroindustri. 2016;4:245-52.

14. Ruzicic RD, Jakovljevic V, Djordjevic D. 
Oxidative stress in training, overtraining and detraining: from experimental to applied research. Serbian Journal of Experimental and Clinical Research. 2016;17(4):343-8.

15. Abubakar O. Pemberian ekstrak kulit terung ungu (Solanum melongena L) menghambat peningkatan MDA dalam darah tikus Wistar yang dinduksi aktivitas fisik maksimal [Tesis]. Denpasar: Universitas Udayana; 2010.

16. Vitariana. Pemberian ekstrak daun kayu manis menurunkan kadar isoprostane dalam urin tikus Wistar yang diberikan beban aktivitas fisik berlebih maksimal [Tesis]. Denpasar: Program Studi Magister Biomedik Universitas Udayana; 2011.

17. Sulaiman Y. Pemberian bisphenol A (BPA) oral dapat menurunkan kadar superoksida dismutase dan meningkatkan kadar F2-isoprostan pada tikus putih (Rattus norvegicus) jantan galur Sprague dawley [Tesis]. Denpasar: Universitas Udayana; 2017.

18. Gibala MJ, Little JP, MacDonald MJ, Hawley JA. Physiological adaptations to low-volume, high-intensity interval training in health and disease. J Physiol. 2012;590(Pt 5):1077-84.

19. Stanojevic D, Jakovljevic V, Barudzic N, Zivkovic V, Srejovic I, Parezanovic Ilic $\mathbf{K}$, et al. Overtraining does not induce oxidative stress and inflammation in blood and heart of rats. Physiol Res. 2016;65(1):81-90.

20. Otitoju O, Onwurah INE, Otitoju GT, Ugwu CE. Oxidative stress and superoxide dismutase activity in brain of rats fed with diet containing permethrin. Biokemistri. 2008;20(2): 93-98

21. Gems D, Doonan R. Antioxidant defense and aging in C. elegans: is the oxidative damage theory of aging wrong? Cell Cycle. 2009; 8(11):1681-7.

22. Zhou KI, Pincus Z, Slack FJ. Longevity and stress in Caenorhabditis elegans. Aging (Albany NY). 2011;3(8):733-53.

23. Widyaningsih TD, Wijayanti N,
Handayani D, Prasetyo G. Antihypertensive effects of black cincau (Mesona palustris BL) effervescent powder and malondialdehyde concentration on Wistar rats as a hypertensive model. Res J Life Sci. 2016;3(2):79-85. .

24. Widyaningsih TD, Sari BTF. Antioxidant and hepatoprotective effect of black cincau (Mesona palustris BL) supplement against oxidative stress in rats. Int J ChemTech Res. 2017;10(2): 44-55

25. Vijayakumar S, Presannakumar G, Vijayalakshmi NR. Investigations on the effect of flavonoids from banana, Musa paradisiaca L. on lipid metabolism in rats. J Diet Suppl. 2008;6(2): 111-23.

26. Imam MZ, Akter S. Musa paradisiaca L. and Musa sapientum L.: A phytochemical and pharmacological review. J App Pharm Sci. 2011;1(5): 14-20.

27. Mot AC, Damian G, Sarbu C, Silaghi DR. Redox reactivity in propolis: direct detection of free radicals in basic medium and interaction with hemoglobin. J Med Food. 2009;14(6): 267-74.

28. Ozyigit II, Filiz E, Vatansever R, Kurtoglu KY, Koc I, Öztürk MX, Anjum NA. Identification and comparative analysis of H2O2-scavenging enzymes (ascorbate peroxidase and glutathione peroxidase) in selected plants employing bioinformatics approaches. Front Plant Sci. 2016;7:301.

29. Leonardo CC, Doré S. Dietary flavonoids are neuroprotective through Nrf2coordinated induction of endogenous cytoprotective proteins. Nutr Neurosci. 2011;14(5):226-36.

30. Huang CS, Lii CK, Lin AH, Yeh YW, Yao HT, Li CC, et al. Protection by chrysin, apigenin, and luteolin against oxidative stress is mediated by the Nrf2-dependent up-regulation of heme oxygenase 1 and glutamate cysteine ligase in rat primary hepatocytes. Arch Toxicol. 2013;87:167-78. 